\title{
Poranění plexu a periferních nervů
}

\section{doc. MUDr. Edvard Ehler, CSc., FEAN - editor hlavního tématu Neurologické oddělení, Nemocnice Pardubického kraje, a. S., Pardubice}

Traumatické léze periferních nervů a méně často plexů jsou častým důvodem k neurologickému ambulantnímu či konziliárnímu vyšetření. S traumatickými lézemi se relativně často setkávají ambulantní neurologové, konziliáři a velmi často elektromyografisté. Je požadována přesná diagnostika - který nerv, lokalizace postižení, rozsah, reverzibilita, indikace kEMG (každý pacient s podezřením na traumatickou lézi periferních nervů) včetně odstupu od úrazu, indikace k provedení zobrazovacích vyšetření (UZ, MRI, AG, CT).

Diagnostika lézí periferních nervů vyžaduje jak přesné anatomické znalosti, tak představu správné funkce jednotlivých pohybových segmentů a poruchy funkce při postižení periferních nervů. Je důležitá znalost nejčastěji se vyskytujících abnormit periferních nervů (např. MartinGruberova anastomóza - motorická vlákna pro určité svaly ruky $v$ inervační oblasti $n$. ulnaris jsou vedena $v$ n. medianus a teprve na predloktí se anomální spojkou dostávají do n. ulnaris). Je dưležité mít i představu o pleteních (pažní, cervikální, lumbální, sakrální) a úrazech těchto pletení. Určité úrazy mívají typické poranění periferních nervů. Je celkem príijatelné, že luxace hlavice pažní kosti bývá provázena lézí n. axillaris. Ovšem málokdo si dovede představit, že suprakondylická dislokovaná fraktura humeru (typický úraz dětí) často mívá v klinickém nálezu také lézi n. interosseus anterior (až na výjimky pouze prechodného trvání). Zatímco dynamické znalosti o nemocech (např. cévní mozkové príhody) vyžadují určitou kombinační schopnost diagnostického a terapeutického uvažování, pak léze periferních nervů a plexů vyžadují přesné znalosti neměnných faktů - anatomie, fyziologie. A tyto znalosti s pribývajícími roky nápadně blednou. Proto i téma poranění plexu a periferních nervư je zčásti zaměřeno na prohlubování znalostí o anatomii, fyziologii, typických situacích při vzniku traumatických nervových poruch.

Dr. Humhej uvádí nové zobrazovací metody (MR traktografie, neurografie) při hodnocení lézí periferních nervů. Je možno uvést, že ještě dlouho předtím, než po úspěšném ošetření prorostou první axony prì reinervaci svalu, jsou průkazné ty pučíci terminání axony pomocí MRI zpracování.

Dr. Kraus se zabývá typem a tíži lézí periferních nervů, ale také uvádí léze pažní pleteně novorozenců a pak celou plejádu nejčastějších lézí periferních nervů u dětí. Jak typické úrazové situace při vzniku lézí nervů, tak jejich klinický obrat je třeba důsledně znát. Není totiž nikdy dosti prostoru ke komplexnímu i důslednému EMG vyšetření u neklidných a plačících dětí (a ochraňujících príbuzných).

Léze periferních nervů u dospělých detailně popisuje dr. Ceé. Znalost této symptomatiky a možností vyšetření jsou důležité pro každého klinika.

V posledním článku se probírají mechanizmy a osudy nemocných s iatrogenními lézemi. Léze způsobené zdravotnickým personálem nejsou nijak řídké a jejich včasné a přiměřené řešení je stálým úkolem. Léze periferních nervư a plexu bývají často posuzovány pro pojištovny či soudy, proto i zdravotnická (neurologická, EMG) dokumentace musí být přesná včetně kvantifikace lézí. 